e-EXTINCTION: AN ILLUSION OF KNOWLEDGE, THE PRESENCE OF IGNORANCE, OR EVOLUTIONARY FATE?

By

Colin Jones*

And

Dr Rob Hecker

Colin Jones

Dr Rob Hecker

University of Tasmania

University of Tasmania

School of Management

School of Management

PO Box 252-16

PO Box 252-16

Sandy Bay

Sandy Bay

Tasmania 7005

Tasmania 7005

Australia

Phone: + 61 (0) 362262826

Australia

Fax: + 61 (0) 362262808

Phone: + 61 (0) 362261774

Fax: + 61 (0) 362262808

Email: Colin.Jones@utas.edu.au

Email: Rob.Hecker@utas.edu.au

$(*)=$ Contact Author 


\title{
e-EXTINCTION: AN ILLUSION OF KNOWLEDGE, THE PRESENCE OF IGNORANCE, OR EVOLUTIONARY FATE?
}

\begin{abstract}
At present, the rate of small firm adoption of the Internet's ubiquitous World Wide Web (the web) far exceeds the actual exploitation its commercial potential. An inability to strategically acquire, comprehend and use external knowledge is proposed as a major barrier to optimal exploitation of the Internet. This paper discusses the limitations of applying market orientation theory to explain and guide small firm exploitation of the web. Absorptive capacity is introduced as an alternative theory that when viewed from an evolutionary perspective provides potentially more insightful discussion. An inability to detect emerging business model dominant designs is suggested to be a mixture of the nature of the technology that supports the Internet and underdeveloped small firm knowledge processing capabilities. We conclude with consideration of the practical and theoretical implications that arise from the paper.
\end{abstract}

KEYWORDS: Small Firms, Market Orientation, Absorptive Capacity, Evolutionary Theory, and The Internet

\section{INTRODUCTION}

The contention of this paper is that current market orientation theory offers a inadequate explanation of firm learning in times of market turbulence. This paper examines the plight of small place-based firms operating in web-impacted environments, i.e. firms whose operations have historically been determined by and confined to a specific geographical location and, environments characterized by new innovative entrants who use the Internet's technologies to provide unprecedented and unique consumer value (Jones \& Hecker, 2003). In this context, 
small refers to those firms with typically less than twenty employees in both product and service markets. Given the numerical domination of such sized firms (Bjerke \& Hultman, 2002) throughout all economies the world over (and the increasing influence of the Internet), this discussion has widespread application. These small firms typically are the main drivers of job creation throughout the world (Birch, 1987) and therefore represent a major driving force behind all regional economies.

Although the history of the Internet dates back to 1957 as a source of United States defence force communications, its approval for commercial use in 1991 heralded the availability of a technology (the web) with seemingly unlimited application. During the next six years, accepted interface designs (e.g. Gopher, Mosaic, Netscape, and Explorer) aided the widespread adoption of the web as a communication and exchange medium. While the disruptive influence of the web has varied across industries, it has nevertheless been an unalterable environmental force. As the business landscape alters, the fitness of any firm is dependent upon the ability to find solutions to problems introduced into the operating environment by technological change. The web has grown at an unprecedented scale and speed with many firms caught off guard finding it increasingly difficult to incorporate it into their operations (Aldrich, 1999). Aldrich and Baker (2001) note that the web’s development has thus far been reliant upon a core technology, that being the web browser (e.g. Microsoft Explorer). The browsers act as a dominant design that facilitates awareness of entrepreneurial opportunities. However, it is at a peripheral technical subsystem level (Murmann \& Tushman, 2001) that much confusion remains and prevents exploitation of the web by many small firms. Initially, there was much optimism that the web’s exploitation by firms would be based upon an appreciation of consumer needs and wants (e.g. Hoffman \& Novak, 1997; Lodish, Morgan \& Kallianpur, 2001). Market-oriented firms (see Narver \& Slater, 1990; Jaworski \& Kohli, 
1993) with advanced learning capabilities would develop new routines and competencies to satisfy the changing needs of consumers, thus enabling adaptation to the changing environment.

However, as Connor (1999) and Wrenn (1997) note, where radical technologies significantly alter market conditions, the ability of consumers to articulate their latent needs is very questionable. Not surprisingly, little evidence presently exists to support this prescriptive view of small firm exploitation of the web. Conversely, growing evidence suggests many small firms in advanced economies have experienced difficulties exploiting the web (Vescovi, 2000; Chaston, Badger, Mangles \& Sadler-Smith, 2001; Plume, 2001; Jones, Hecker \& Holland, 2002; Van Beveren \& Thomson, 2002). This is hardly surprising given the unique marketplace interactions specific to each firm, its customers, employees and suppliers through which the web’s interactive technologies must diffuse. Given that the long-term survival of all firms depends upon the fit between their routines and competencies and the characteristics of their operating environment (Aldrich, 1999), the viability of many small placed-based firms may be uncertain.

The paper is structured as follows. First, the shortcomings of applying prescriptive market orientation theory (Narver \& Slater, 1990; Jaworski \& Kohli, 1993) to explain and advance the developing nexus between small firms, the web and their operating environment are discussed. Second, the nature of knowledge is considered from a small firm perspective. Third, Zahra and George’s (2002) reconceptualization of the absorptive capacity (Cohen \& Levinthal, 1990) construct is explored to expand discussion of the specific obstacles to small place-based firm survival within web-impacted environments. Fourth, the consequences of 
inadequate firm learning are considered from an evolutionary perspective. Finally, the practical and theoretical implications that arise from the paper are considered.

\section{MARKET ORIENTATION: AN ILLUSION OF KNOWLEDGE?}

Largely due to the influential contributions of Narver and Slater (1990) and Kohli and Jaworski (1990), the presence of degrees of market orientation has been assumed to exist in all firms. In comparison to the customer focussed marketing concept (Houston, 1986) and its operationalized form, the marketing orientation (McCarthy \& Perreault, 1990), a market orientation gathers intelligence on customers, competitors and markets, all apparently essential to small firm exploitation of the web (Hoffman \& Novak, 1997). Hunt and Morgan (1995) distinguish market orientation from the other two constructs by noting that a market orientation:

Is not the same thing as, nor a different form of, nor the implementation of, the marketing concept. Rather, it would seem that a market orientation be conceptualised as supplementary to the marketing concept. Specifically, ...we propose that a market orientation is (1) the systematic gathering of information on customers and competitors, both present and potential, (2) the systematic analysis of the information for the purposes of developing market knowledge, and (3) the systematic use of such knowledge to guide strategy recognition, understanding, creation, selection, implementation, and modification (1995:11).

Despite the jewel in the crown status afforded market orientation by marketing theorists, conceptualization and subsequent measurement issues have continually attracted the attention of sceptics (e.g. Gable, 1995; Wrenn, 1997; Henderson, 1998; Caruana, 1999; Gauzente, 
1999; Jones et al., 2002). Debate continues as to what constitutes a market orientation, how is it best measured and ultimately, what is its influence? For researchers of small firms, the use of market orientation theory to further understand the evolution of firm routines and competencies would seem an invitation to further scepticism. Despite assertions of the applicability of market orientation theory to small firms (Pelham \& Wilson, 1996), the findings of Jones et al., (2002) cast added concern over the theory's place in relatively simple operating structures.

The case-based qualitative and quantitative method used by Jones et al., (2002) exposed a distinct lack of strategic development and use of market knowledge to exploit the web. The firms appeared confused between anticipated behaviors and actual behaviors when completing the Pelham and Wilson (1996) market orientation questionnaire. The recorded high degrees of market orientation for both marketplace and marketspace undoubtedly did not accurately reflect a true comparison of the firm's abilities to acquire and use market knowledge across both domains. Clearly an issue of what popular market orientation instruments actually measure must be resolved to remove the illusion that knowledge exists from which conclusions can be drawn.

It is also argued (Min, Song \& Keebler, 2002) that the validity of the market orientation theory as developed in the non-web context, does not explicitly consider the nature of information transmission within web-impacted environments. Previously, a market orientation was considered necessary and largely sufficient to ensure optimal firm learning (Slater \& Narver, 1995). However, recently Slater (2001) states that a market orientation while necessary for optimal firm learning is not sufficient to support the sense and respond behaviors critical to firm adaptation in dynamic and turbulent markets. The implications being 
that higher-order (generative) learning processes and not traditional market oriented behaviours are perhaps better predictors of firm learning.

That higher-order learning is an outcome of market orientation, separate to, or an inclusive process through which firms convert information into the knowledge that guide's strategy development is not resolved by the extant literature. Slater and Narver (1995:67) claim, "market orientation is the principle cultural foundation of the learning organization". They also claim that market oriented firms are more likely to be generative learners through the need to use techniques that identify customers’ latent needs (Slater \& Narver, 1998). The suggestion appears to be that market oriented behaviours (the gathering, disseminating and strategic transformation of intelligence into knowledge) are reliant upon generative learning processes to transform intelligence into valuable knowledge. However, Narver and Slater's (1990) accepted market orientation scale does not include items related to the firm's openmindedness or the propensity to challenge past assumptions. As such, there appears a leap of faith within the extant literature regarding the actual learning processes engaged in by marketoriented firms.

With reference to organizational learning and market orientation, Baker and Sinkula (2002:8) cast market orientation as a separate construct that "reflects the quantity of a firm's market information processing activities and the weight that these activities have on the strategic planning process. It does not reflect the quality of a firm's market information processing activity”. This view is consistent with assertions that the presence of a market orientation alone will not guarantee higher-order learning processes through which optimal outcomes are achieved (Dickson 1996; Jaworski \& Kohli 1993). In short, market orientation theory does little to explain the speed, direction, and intensity of the firm's search for external knowledge. 
It doesn't differentiate between information sought (and received) that complements the firm's existing knowledge base, and information that is foreign to the firm's knowledge base. It ignores the importance of the firm's absorptive capacity (Cohen and Levinthal 1990) thereby overlooking the importance of prior knowledge to assist recognition of new information. The web is likely to represent a novel domain with exploitation dependent upon the broadening of existing knowledge bases. It would therefore seem that the application of traditional market orientation theory within the context discussed is problematic.

It would seem that market orientation theory has been emerged as a result of the failure of the marketing concept to gain acceptance by other academic disciplines (e.g. economics). The theory is at best a concept based upon a logical philosophy: If you all pull together to satisfy the customer, superior performance will ensue. However, the nature of knowledge, how it is acquired and how its value is determined before use are scarcely discussed within the literature pertaining to market orientation. What is missing is a detailed account of how individual firms learn, what is the firm's knowledge and where does it come from and subsequently reside once it is acquired.

\section{THE REALITY OF KNOWLEDGE}

It is important to recognise that knowledge is not an absolute thing. It is based upon individual (or shared sets of) beliefs regarding the causal relationships among phenomena (Sanchez \& Heene, 1997). We argue that a small firm's ability to adapt to a rapidly changing environment is dependent upon the stock of working knowledge that represents its history, routines, competencies, and market positioning. Davenport and Prusak define a firm's working knowledge as: 
A fluid mix of framed experience, values, contextual information, and expert insight that provides a framework for incorporating new experiences and information. It originates and is applied in the minds of knowers. In organizations, it often becomes embedded not only in documents or repositories but also in organizational routines, processes, practices, and norms (1998:5).

This suggests that knowledge simultaneously resides not only within individuals but also within the firm and its activities. Some of this knowledge is said to be tacit and "therefore hard to formalize and communicate” (Nonaka \& Takeuchi, 1995:59). Further, Nonaka and Takeuchi state that some of the knowledge will be more explicit due to its codification and dissemination via formal means (e.g. documentation). The SECI model of Nonaka and Takeuchi proposed that knowledge management (or creation) was dependent upon the interaction between tacit and explicit knowledge. They suggest a process of socialization, externalization, combination, and internalization provides a never-ending spiral of knowledge that enables firms to convert tacit knowledge (which is of limited value) into a more usable and explicit form of knowledge.

However, debate currently exists as to the practicalities of such prescriptive theory. From the perspective of the small place-based firm, the costs associated with the codification of tacit knowledge may exceed the benefits (Snowden, 2002) of ensuring all employees are aware of and understand the stock of working knowledge the firm has. This raises questions regarding the ability of firms to leverage and control tacit knowledge or whether or not it is actually possible to fully comprehend the context that underlies the tacit knowledge (Sanchez, 1997). Within the context of web-impacted environments it is not easy to see how a small bookseller in Australia would acquire tacit knowledge about the operations of Amazon.com. However, in 
order to press on with an alternative view that has more substance than market orientation theory, this codification debate while acknowledged, is not addressed further in the paper. It is however acknowledged that there is a likely inseparability of knowledge between individual and firm, and that some of this knowledge will be more difficult to communicate or comprehend. As such, small firm learning is seen as an interactive process occurring across entities (e.g. individuals, routines, firms, populations of firms, and the operating environment) that is governed by specific events (e.g. start-up and adaptation). Therefore, in web-impacted environments, it is proposed that it is the flow of knowledge across those entities rather than the management of specific knowledge content that most determines firm's working knowledge. The following discussion outlines an alternative perspective of knowledge creation.

\section{ABSORPTIVE CAPACITY: THE DISCOVERY OF IGNORANCE}

It will be argued that the reconceptualization of the absorptive capacity construct by Zahra and George (2002) provides a mechanism through which the fit between the firm's working knowledge and the changing environment can be reconciled. Since the seminal contribution of Cohen and Levinthal (1990), absorptive capacity has been associated with the acquisition and use of knowledge to enhance firm performance through increased learning and innovation (e.g. Keller, 1996; Liu \& White, 1997; Kim, 1998). Cohen and Levinthal defined absorptive capacity as the "ability to recognize the value of new information, assimilate it, and apply it to commercial ends (1990:128). Originally operationalized as a single factor component with three dimensions (i.e. valuing, assimilating, and applying new knowledge), the potential influence of absorptive capacity was understood to be dependent upon the firm's prior knowledge base and skills. 
However, in their reconceptualization, Zahra and George (2002:186) define absorptive capacity as having two distinct components that together are operationalized as "a set of organizational routines and processes by which firms acquire, assimilate, transform, and exploit knowledge to produce a dynamic organizational capability” (2002:186). Within this new definition are two specific components, potential (i.e. acquisition and assimilation) and realized (i.e. transformation and exploitation) absorptive capacity. Potential absorptive capacity is the capability to sense what information is relevant, acquire it, analysis it, comprehend it and internalise it. As such, it provides the firm an appreciation of the exogenous environmental forces that may or may not favour the firm's existing routines. Realized absorptive capacity relates to the routines that blend existing knowledge with newly acquired knowledge to gain new insights to opportunities or problems and provide structured pathways to develop new competencies. In aggregate, the two components potential provide the foundation of "a dynamic capability pertaining to knowledge creation and utilization" (Zahra \& George, 2002:185). When viewed from an evolutionary perspective, it is argued that this interpretation of the absorptive capacity construct supports discussion of how, why, and when individual firms learn about environmental change.

We propose that small firm learning is subsumed within the evolutionary processes of variation, selection and retention given that:

Evolutionary theory unites in a single coherent framework a concern for the entrepreneurial outcomes and the processes and contexts making them possible. An evolutionary approach studies the creation of new organizational structures (variation), the way in which entrepreneurs modify their organizations and use resources to survive in changing environments (adaptation), the circumstances 
under which such organizational arrangements lead to success and survival (selection), and the way in which successful arrangements tend to be imitated and perpetuated by other entrepreneurs (retention)( Aldrich \& Martinez , 2001:42).

This view of small firm learning recognises the adaptive role of the owner/manager in response to both environmental uncertainty and their prior actions (Deakins \& Freel, 2003). As such, optimal learning behaviours stem from generative learning behaviours in which firms learn through the meaningful integration of new and old knowledge related to their experiences. We propose that a small firm's willingness and ability to acquire and assimilate external knowledge (i.e. potential absorptive capacity) related to the web, provides exposure and awareness to crucial variations that may potentially be incorporated into new business models. Also, we suggest that without the ability to transform and exploit existing and newly acquired knowledge (i.e. realized absorptive capacity), existing routines and competencies are likely to be retained (or unwisely altered), thus preventing adaptation to web-impacted environments.

Such processes would seem to make a valuable contribution to Aldrich's (1999) interdisciplinary evolutionary framework though which the processes of variation, selection and retention support patterns of change within firms. This view is based on Zahra and George's (2002) broader interpretation of the absorptive capacity construct, a dynamic capability related to firm learning associated with the development of new routines and competencies. As such, a far greater level of analysis is possible than that of market orientation theory where relatively higher degrees of market-orientedness (within an industry) are assumed the basis for future prosperity. 
Absorptive capacity is a versatile theory that together with evolutionary theory supports discussion of small place-based firm adaptation to web-impacted environments. At present, the changing nature of such business environments threaten to reduce the fitness of existing firm's routines and competencies. Such a maladjustment (Santos, 2002) may well result in the e-extinction of many small place-based firms. While the presence of potential absorptive capacity does not ensure knowledge exploitation, it does nevertheless reduce the firm's ignorance of extant business model variations. Correspondingly, the value of routines associated with realized absorptive capacity is largely reliant upon the nature of the external knowledge introduced. The assertion is that together, both subsets of absorptive capacity increase firm responsiveness to environmental change and facilitate adaptation.

\section{Ignorance of the Invisible}

Currently, an era of technological ferment exists with many existing small firms experimenting with varieties of web applications. Four basic business models options are possible; stay place-based without connecting, stay place-based and use a shopping mall (portal) to exploit the web, integrate the web within existing place-based assets, or reject place-based operations in favour of a pure web model (e.g. Amazon.com). As yet however, a dominant design for successfully conducting exchange on the web, regardless of the business model chosen, seems elusive. Tushman and Murmann (1998) note new dominant designs are dependent upon patterns of variation, selection and retention at the subsystem level that ultimately effect firm and industry change. Given the resource poorness of many small firms, identification of a particular business model that will be both efficient and effective is a major challenge. Also, the volume of web-based exchange in many industries is still relatively low restricting the observability of variations upon which new dominant designs are conditional. 
This paper posits that the degree of potential absorptive capacity will influence exposure to and appreciation of such variations.

This capability is deemed important given that dominant designs are only known in retrospect and then only after only they account for over $50 \%$ of exchange against competing designs (Anderson \& Tushman, 1990). Despite optimism that transformation of the firm during such uncertainty is plausible (Ruef, 1997), our thesis is that many firms, and especially small firms, will experience difficulty learning in rapidly changing environments. This view is premised upon recognition that small firm exploitation of a complex innovation such as the web is typically dependent upon external knowledge. In the absence of acquiring and strategically using external knowledge, it is possible that the web may only represent an efficient medium for communications and acquiring generic information (Jones et al., 2002). Even in situations where small firms experiment with sub-system components (e.g. payment devices, delivery capabilities, real-time capabilities, advertising and communications) and the linking mechanisms that comprise the product or service, learning by doing is no guarantee of adaptation.

Adaptation by small firms by exploitation of the web requires the development of different knowledge bases, typically from new knowledge sources. In the absence of new knowledge, exploitation of the web is limited by the technological paradigm within the firm (Dosi, 1984) that governs the normal patterns of problem solving or opportunity exploitation. Such paradigms may prevent the firm from fully appreciating the potential of the web's technologies regarding new value creation. Without access to external knowledge firms are less likely to develop the necessary potential absorptive capacity to understand the nature of the web. Given that small firms typically have less internal resources at their disposable to 
evaluate both environmental threats and opportunities (Lang, Calantone \& Gudmundson, 1997), reliance upon external sources may be intensified. Under such circumstances the web, despite being a source of new variation and a catalyst to altering the existing selection criteria (Aldrich, 1999), may also pose a threat.

The emergence of the web can be viewed as a technological triggering event, expected to promote firms to increase their efforts to seek external knowledge from the market related to developing forms of web-based value for their customers. However, in many cases the required knowledge base is new and not merely an extension of the existing. Consequently, acquiring knowledge from a novel domain without prior knowledge challenges the ability to develop potential absorptive capacity (Cohen \& Levinthal, 1990). Compounding the situation is the difficulty small firms face in locating technology linkers who can understand how their core activities relate to web-based opportunities and guide their exploitation (Plume, 2001; Jones et al., 2002). The technology linker is the person/s responsible for transferring specific knowledge related to exploiting the web’s technologies from the market to the firm (Marshall \& Reday, 2001). It is common for this role to be performed by Information Technology consultants. However, given the limited scope of small firm operations, the responsibility of this role may fall to persons without the necessary ability to adequately transfer such knowledge, for example, the local Internet Service Provider (Jones et al., 2002). This may result in existing internal selection processes promoting persistence rather than change. In such situations small firms could become stymied, unable to adequately understand variations and ignorant of external environmental selection forces. Penrose suggests that an imbalance between embodied technology (e.g. the web’s hardware) and disembodied technology (e.g. know-how of the web) would prove detrimental to optimally exploit new technologies, stating that: 
Both an automatic increase in knowledge and an incentive to search for new knowledge are, as it were, 'built into' the very nature of firms possessing entrepreneurial resources of even average initiative. Physically describable resources [i.e. the web] are purchased in the market for their known services; but as soon as they become part of the firm the range of services they are capable of yielding [i.e. business model variation] starts to change. The services that the resources will yield depend on the capacities of the men using them, but the development of the capacities of the men is partly shaped by the resources men deal with [i.e. prior knowledge]. The two together create the special productive opportunity of a particular firm. The full potentialities for growth provided by this reciprocal change will not necessarily by realized be any given firm, but in so far as they are realized, growth will take place that cannot be satisfactorily explained with reference only to changes in the environment of the firm (1959:78-79).

Thus, the interaction between potential and realized subsets of absorptive capacity endows capabilities that enable the exploitation of new technologies. Without such capabilities, firms intent on exploiting the web may gain only sub-optimal returns from their initial investments. For instance, how does the local bookseller employ the technologies of the web to adapt to his/her operating environment? Within the book selling industry it is very apparent what is possible through combining the web and bookselling. What is not apparent however, is the process required to build economies of scale through developing a global or regional community of web-based users. In the absence of knowledge of this process, it is more likely that web's technologies will contribute to lower communication costs (e.g. email) and other 
internal efficiencies. These benefits while worthwhile do little to prevent maladjustment occurring within web-impacted environments.

\section{EVOLUTIONARY FATE}

Clearly the web has been the catalyst for much variation within many industries. Small placebased firms in web-impacted environments are seemingly under increasing pressure to incorporate the web into existing operations. Unlike previous forms of directly observable competition, emerging web-based business model variations that are more favoured by consumers (e.g. Amazon.com) remain largely unobservable to many small place-based firms. It is likely that change agents who promote the web's virtues may introduce it as an intentional variation. However, as previously noted, little evidence exists to support small firm selection of new routines and competencies associated with the exploitation of the web. This may be due an inability to acquire the know-how knowledge (e.g. information necessary to fully exploit the web) and principle knowledge (e.g. information relating to the web's theoretical underpinnings) (Rogers, 1995) vital to assimilating the web into existing routines and competencies.

Again, a firm's inability to develop potential absorptive capacity may be limited by a lack of prior knowledge (Cohen \& Levinthal, 1990) related to the web. Consequently, increased complexity of learning may result in firms struggling to acquire, comprehend and implement knowledge associated with new routines and competencies (McKelvey, 1982). Barriers may exist through geography such as an inability to adequately observe the operations of marketspace firms, and through legalities such as Amazon.com's patented one-click payment system. These barriers can decrease exposure to variations thereby restricting a firm's ability to change. This is because the firm must bridge the knowledge gap between what is known 
and what is not through difficult to acquire and assimilate (and therefore difficult to transform and exploit) foreign knowledge bases. It is also possible that routines imprinted into firms (Tucker, Singh \& Meinhard, 1990) prior to the emergence of the web may not support the learning behaviors required to adapt to the web. Again, the suggestion is that small firms that demonstrate the ability to develop potential absorptive capacity are more likely to expose themselves to variations from which new business models may emerge. Through awareness of marketplace variations, a transformation involving major change in the firm over time and representing a substantial variation, planned or unplanned, that has been selected and retained (Aldrich, 1999) is unlikely. Despite the fact that variation and retention are at odds with each other, the processes of variation, selection and retention are all required to enable firm adaptation to the web. So it would seem that a small place-based firm's inability to discern variations within web-impacted environments, may represent a major obstacle to their survival.

As a mechanism for commercial exchange, the web represents a technological breakthrough capable of jolting existing selection criteria through recognition of external opportunities or threats. Without such disruption, internal selection criteria may continue to act as "vicarious representatives of past external criteria that are no longer relevant” (Aldrich, 1999:174). Perceived as either a competence-enhancing (opportunity) or competence-destroying (threat) (Tushman \& Anderson, 1986) technological event, the web may strengthen or weaken a firm's position within an industry. However, Aldrich (1999) with reference to Hunt and Aldrich (1998) suggests an alternative view exists to Tushman and Anderson's dichotomy. The web can be viewed as a competence-extending innovation that permits: 
Existing firms to pursue new opportunities that allow them to stretch their existing competencies into complementary ventures. Unlike competence-enhancing opportunities, these new ventures are not a straightforward extension of their current routines and competencies and therefore cannot be pursued with minimal effort. At the same time, however, these opportunities are not direct threats to their existing business pursuits and competencies. Instead, they are potential opportunities for expanding their domains by pursuing new markets through exploitation of new competencies (1999:315).

From this perspective, the ability of small firms to develop absorptive capacity would seem central to their development and exploitation of the new knowledge bases from which new variations would be selected. For those firms who sense industry variations in routines and competencies, two approaches to the web are likely, ignore emerging variations or adopting a Lamarckian posture to intentionally exploit the web. Given the focus of this paper to discuss potential obstacles to small firm survival in web-impacted environments, the latter is considered.

Consistent with the basic tenets of the absorptive capacity, the Lamarckian evolutionary view holds that "organizations exist in environments and are responsive to environmental forces" (McKelvey, 1982:242). From this perspective small firms may seek to identify specific niches that promote the value of their physical assets, use the web’s reach to enter new markets, or a combination of both. However, despite a small firm's deliberate intention to consider new variations, external selection pressures may prevent transformation occurring. Grant (1985) and Amburgey, Dacin and Kelly (1994) suggest that external selection processes can be considered in three general patterns, stabilizing, directional, and disruptive. As previously 
noted, dominant designs for small firm use of the web are by and large yet to crystallize. Therefore, stabilizing selection (e.g. the reduction of variance) is not a significant issue as yet. However, directional selection pressures (e.g. movement of the mean along some dimension) and disruptive selection pressures (e.g. removal of some firms from the population's extreme interior distribution along some dimension to form a new population) are likely to impact small firms.

Given any ongoing change in consumer behaviour that favours the web, small firms who sense (an respond to) such change may be favoured by directional pressure more so than those who do not. Also, in the instance of firms attempting to incorporate the web’s technology into existing routines and competencies, those with a history of previous change may do so more efficiently than firms with strong overriding internal selection processes. It may also be that firms, irrespective of size, with access to specific resources (e.g. capital, technical knowledge and learning capabilities) that support exploitation of the web will be favoured. For example, large firms may enter new (and distant) markets while small firms may exploit their unique closeness to their customer base. Firms that have neither access to the resources required to expand, or have in place strong customer relationships, may be disruptively selected out of their industry.

The necessary degree of evolutionary transformation can be observed through content changes within the firm's goals, boundaries and activities (Aldrich, 1999). While it may appear many small firms have made changes within their activities (e.g. email and increased information searching capabilities) that potentially impact the nature of their knowledge processing, it is the scope and depth of their influence that matter (Aldrich, 1999). For example, returning to the example of the small bookseller in Australia, what changes does 
connecting to the web bring? If the web has not altered the focus of the shop (i.e. its target market and offerings), changed the nature of the entity vis-à-vis the operating environment, or required the overhaul of existing activity systems, then little transformation could be said to have occurred. Clearly, a web presence without obvious strategic intent may create awareness, but technology is not a substitute for strategy (Rangan \& Adner, 2001). Given the difficulty in isolating and communicating with a specific target market on the web (Hoffman \& Novak, 1996), transformation of the firm cannot be achieved by merely connecting to the web. This is because the web as a technology is a constant; it is the human agent that seeks to exploit the technology that must develop (Veblen, 1919). Clearly, the firm's goals and the domain of operation must be matched with consideration of boundary expansion or contraction and the development of activities (e.g. routines and competencies) that support the process of transformation. Such a process would be complete when the knowledge required to replicate this variation is embodied within the firm (Aldrich, 1999).

In summary, survival within web-impacted environments cannot be guaranteed by the presumption of knowledge, and is more likely to be denied through the ignorance of variations present within the operating environment. While directional and disruptive selection pressures may overwhelm small firms, access to and exploitation of external knowledge increase awareness of variations and potentially decrease the influence of external selection pressures. As such, the occurrence of maladjustment between the operating environment and small place-based firms who develop absorptive capacity would appear less likely. 


\section{CONCLUSION}

At present, survival appears reserved for those small place-based firms who can navigate the uncertainty associated with web-impacted environments. This paper speculates that the process of firm adaptation will be smoother for those small firms whose existing routines and competencies already support the acquisition and assimilation of external knowledge from novel domains. The assumption that increased levels of market-orientedness can be relied upon to ensure small firm survival within web-impacted environments has been discussed. Market orientation theory would appear deficient in its application as to how and why small firms may succeed or face e-extinction attempting to exploit the web. Zahra and George’s (2002) absorptive capacity construct was introduced as a compatible theory through which more insightful discussion on emerging dominant design is possible. The implications that arise from the discussion for policy makers is that the nature of programmes aimed at supporting small firm adoption of the Internet should acknowledge the likelihood of learning difficulties. Without effective technology linkers to assist small firms comprehend the complexities of acquiring, assimilating, transforming and exploiting external knowledge related to the web's technologies, the success of current assistance programmes are likely to be over reliant upon chance. Clearly, it would seem very important that assistance providers understand how the process of small firm learning relates to the optimal adoption of the web.

Therefore, a specific research opportunity arises from the above discussion. Given the numerical domination of small firms throughout many industries and the ubiquitous and rapid influence of the web, research into the small firm adaptation would appear needed more than ever. Confirming a link between the absorptive capacity construct and evolutionary theory would enable the exploration of specific routines and competencies supportive of adaptation within web-impacted environments. Confirmation of such a relationship would contribute to 
the field of entrepreneurship by revealing processes through which market opportunities are discovered and subsequently exploited, a critical issue in entrepreneurship theory (Alvarez \& Barney, 2002). For example, evidence of potential absorptive capacity through which profitable variations are identified and realized absorptive capacity through which such variations are selected and retained would advance understanding of firm specific processes that support new enterprise. This approach would require the unit of analysis to be the routines and competencies, with firms considered their hosts (Aldrich, 1999). This also requires that existing small firms are not the sole domains of data collection. Consideration is also needed of both disbanded small firms and the intentions of nascent entrepreneurs. This may increase the identification of intentional and blind (i.e. chance) variations and the selection forces that determine the distribution of such routines and competencies within a specific population. Discovery of a specific relationship between absorptive capacity and evolutionary theory may therefore provide a plausible explanation of what drives the variation, selection and retention processes essential for adaptation within changing environments.

\section{REFERENCES}

Aldrich, H.E. (1999). Organizations evolving. London: Sage Publications.

Aldrich, H.E. and Baker, T. (2001). Learning and legitimacy: Entrepreneurial responses to constraints on the emergence of new populations and organizations. In Schoonhoven, C.B. and Romanelli, E. (Eds.), The entrepreneurship dynamic: Origins of entrepreneurship and the evolution of industries, pp. 207-235. California: Stanford University Press.

Aldrich, H.E. and Martinez, M.A. (2001). Many are called, but few are chosen: An evolutionary perspective of the study of entrepreneurship, Entrepreneurship Theory and Practice, 25(4): 41-56.

Amburgey, T.L., Dacin, T. and Kelly, D. (1994). Disruptive selection and population segmentation: Interpopulation competition as a segregating process. In Baum, J.A.C. and Singh, J.V. (Eds.), Evolutionary dynamics of organizations, pp. 240-254. New York: Oxford University Press. 
Anderson, P. and Tushman, M. (1990). Technological discontinuities and dominant designs: A cyclical model of technical change. Administrative Science Quarterly, 35, 604-633.

Alvarez, S.A and Barney, J.B. (2002). Resource-based theory and the entrepreneurial firm. In Hitt, M.A., Ireland, R.D., Camp, S.M. and Sexton, D.L. Strategic Entrepreneurship: Creating a new mindset, pp. 89-105. Cornwall: Blackwell Publishing.

Baker, W.E. and Sinkula, J.M. (2002). Market orientation, learning orientation and product orientation: Delving into the organization's black box. Journal of Market-Focused Management, 5, 5-23.

Birch, D. (1987). Job creation in America: How our smallest companies put the most people to work. New York: Free Press.

Bjerke, B. and Hultman, C. (2002). Entrepreneurial marketing: The growth of small firms in the new economic era. Cheltenham: Edward Elgar.

Caruana, A. (1999). An assessment of the dimensions and the stability of items in the MARKOR Scale. Marketing Intelligence \& Planning, 17, 248-253.

Chaston, I., Badger, B., Mangles, T. and Sadler-Smith, E. (2001). The Internet and ecommerce: An opportunity to examine organisational learning in progress in small manufacturing firms. International Small Business Journal, 19(2): 134-147.

Cohen, W.M. and Levinthal, D.A. (1990). Absorptive capacity: A new perspective on learning and innovation. Administrative Science Quarterly, 35(March): 128-152.

Connor, T. (1999). Customer-led and market-oriented: A matter of balance. Strategic Management Journal, 20(12): 1157-1163.

Davenport, T.H. and Prusak, L. (1998). Working knowledge: How organizations manage what they know. Boston, MA: Harvard Business School Press.

Deakins, D. and Freel, M. (2003). Entrepreneurship and small firms, Sydney: McGraw-Hill.

Dickson, P.R. (1996). The static and dynamic mechanics of competition: A comment on Hunt and Morgan's comparative advantage theory. Journal of Marketing, 60(October): 102-106.

Dosi, G. (1984). Technical change and industrial transformation. Hong Kong: MacMillin Press.

Gable, T.G. (1995). Market orientation: theoretical and methodological concerns. In Proceedings of the American Marketing Association Summer Educators' Conference (Eds).

B. B. Stern and G. M. Zinkham. Chicago II: American Marketing Association, pp.368-375.

Gauzente, C. (1999). Comparing market orientation scales: A content analysis. Marketing Bulletin, 10, 76-82.

Grant, V. (1985). The evolutionary process: A critical review of evolutionary theory. New York: Columbia University Press. 
Henderson, S. (1998). No such thing as market orientation - a call for no more papers. Management Decision, 36, 598-609.

Hoffman, D.L. and Novak, T.P. (1996). Marketing in hypermedia computer-mediated environments: conceptual foundations. Journal of Marketing, 60(3): 50-69.

Hoffman, D.L. and Novak, T.P. (1997). A new marketing paradigm for electronic commerce. The Information Society, 13(1): 43-55.

Houston, F.S. (1986). The marketing concept: What it is and what it is not. Journal of Marketing, 50 (April): 81-87.

Hunt, S.H. and Morgan, R.M. (1995). The comparative advantage theory of competition. Journal of Marketing, 59(April): 1-15.

Hunt, C.S. and Aldrich, H.E. (1998). The second ecology: The creation and evolution of organizational communities as exemplified by the commercialization of the world wide web. In Staw, B.M. and Cummings, L.L. (Eds.), Research in organizational behavior, pp. 267-302. Greenwich, CT: JAI Press.

Jaworski, B.J. and Kohli, A.K. (1993). Market orientation: Antecedents and consequences. Journal of Marketing, 57(3): 53-71.

Jones, C., Hecker. R. and Holland. P. (2002). Small firm Internet adoption: A market oriented approach. Australian Journal of Information Systems, 10(1): 99-109.

Jones, C. and Hecker, R. (2003). Small e-firms: enlightened butterflies, or endangered caterpillars. Paper presented at the $16^{\text {th }}$ Small Enterprise Association of Australia and New Zealand, Ballarat.

Keller, W. (1996). Absorptive capacity: On the creation and acquisition of technology in development. Journal of Developmental Economics, 49, 199-210.

Kim, L. (1998). Crisis construction and organizational learning: Capability learning in catching-up at Hyundai Motor. Organization Science, 9, 506-521.

Lang, J.R., Calantone, R.J. and Gudmundson, D. (1997). Small firm information seeking as a response to environmental threats and opportunities. Journal of Small Business Management, 35(1): 11-23.

Lodish, L.M., Morgan. H.L. and Kallianpur, A. (2001) Entrepreneurial marketing. New York: John Wiley \& Sons.

Liu, X. and White, R.S. (1997). The relative contributions of foreign technology and domestic inputs to innovation in Chinese manufacturing industries. Technovation, 17, 119-125.

Marshall, R. and Reday, P.A. (2001). Technology transfer in marketing exchanges: The characteristics of the technology linker. Journal of Euromarketing, 10(2): 49-66. 
McCarthy, J.E. and Perreault, W.D. (1990). Basic marketing: A managerial approach $\left(10^{\text {th }}\right.$ ed.). Homeward IL: Irwin.

McKelvey, B. (1982). Organizational systematics: Taxonomy, evolution, classification. London: University of California Press.

Min, S., Song, S. and Keebler, J.S. (2002). An Internet-mediated market orientation (IMO): Building a theory. Journal of Marketing Theory and Practice, 10(2): 1-11.

Murmann, J.P. and Tushman, M.L. (2001). From the technology cycle to the entrepreneurship dynamic: The social context of entrepreneurial innovation. In Schoonhoven, C.B. and Romanelli, E. (Eds.), The entrepreneurship dynamic: Origins of entrepreneurship and the evolution of industries, pp. 178-203. California: Stanford University Press.

Narver, J.C. and Slater, S.F. (1990). The effect of market orientation on business profitability. Journal of Marketing, 54(October): 20-35.

Nonaka, I. and Takeuchi, H. (1995). The knowledge-creating company: How Japanese companies create the dynamics of innovation. New York: Oxford University Press.

Pelham, A.M. and Wilson, D. (1996). A longitudinal study of the impact of market structure, and market orientation culture on dimensions of small-firm performance. Journal of the Academy of Marketing Science, 24 (1): 27-43.

Penrose, E.T. (1959). The theory of the growth of the firm. London: Basil Blackwell.

Plume, H. (2001). Survival of the e-fittest.

http://www.capcollege.bc.ca/admin/Formedia/2001releases/ebiz.html. Accessed on 5/8/2001.

Rangan, S. and Adner, R. (2001) Profits and the Internet: Seven misconceptions. Sloan Management Review, 42(4): 44-53.

Rogers, E.M. (1995). Diffusion of innovations ( $4^{\text {th }}$ ed.). New York: The Free Press.

Ruef, M. (1997). Assessing organizational fitness on a dynamic landscape: An empirical test of the relative inertia thesis. Strategic Management Journal, 18(11): 837-853.

Sanchez, R. (1997). Managing articulated knowledge in competence-based competition. In Sanchez, R. and Heene, A. (Eds.), Strategic learning and knowledge management, pp. 163187. Brisbane: John Wiley \& Sons.

Sanchez, R. and Heene, A. (1997). A competence perspective on strategic learning and knowledge management. In Sanchez, R. and Heene, A. (Eds.), Strategic learning and knowledge management, pp. 3-15. Brisbane: John Wiley \& Sons.

Santos, M.V. (2002). The phenomenon of organizational evolution: A model for analysis. Leadership \& Organization, 23(4): 215-227.

Slater. S.F. (2001). Market orientation at the beginning of a new millennium. Managing Service Quality, 11, 230-232. 
Slater, S.F. and J. C. Narver. (1995). Market orientation and the learning organization. Journal of Marketing, 58(July): 63-74.

Slater, S.F. and J. C. Narver. (1998). Customer-led and market-oriented: Lets not confuse the two. Strategic Management Journal, 19(10): 1001-1006.

Snowden, D. (2002). Complex acts of knowing: Paradox and descriptive self-awareness. Journal of Knowledge Management, 6(2): 100-111.

Tucker, D.J., Singh, J.V. and Meinhard, A.G. (1990). Founding characteristics, imprinting, and organizational change. In Singh, J.V. Organizational evolution: New directions. pp. 182200. London: Sage Publications.

Tushman, M.L. and Anderson, P. (1986). Technological discontinuities and organizational environments. Administrative Science Quarterly, 31, 439-465.

Tushman, M.L. and Murmann, J.P. (1998). Dominant designs, innovations types, and organizational outcomes. In Staw, B.M. and Cummings, L.L. (Eds.), Research in organizational behavior. pp. 231-253. Greenwich, CT: JAI Press.

Van Beveren, J. and Thomson, H. (2002). The use of electronic commerce by SMEs in Victoria, Australia. Journal of Small business Management, 40(3): 250-253.

Vescovi, T. (2000). Internet communication: The Italian SME case. Corporate Communications: An International Journal, 5(2): 107-111.

Veblen, T. (1919). Why economics is not an evolutionary science. In: Veblen, T. The place of science in modern civilisation, New York: Huebsch (56-81).

Wrenn, B. (1997). The market orientation construct: Measurement and scaling issues. Journal of Marketing Theory and Practice, 5(3): 31-54.

Zahra, S.A. and George, G. (2002). Absorptive Capacity: A review, reconceptualization, and extension. Academy of Management Review, 27(2): 185-203. 